\title{
Seismic risk of critical facilities in the Dominican Republic: case study of school buildings
}

\author{
N. J. Rojas-Mercedes ${ }^{1}$ (D) $\cdot$ L. Di Sarno ${ }^{2,3}$ (D) A. L. Simonelli ${ }^{1}$ A. Penna ${ }^{3}$
}

Published online: 25 September 2019

(C) The Author(s) 2019

\begin{abstract}
The island of Hispaniola, shared by the Dominican Republic and Haiti, is located in a subduction zone between the North America plate and the Caribbean plate. In addition, there are 13 geological faults in the interior of the island, some of which have shown the potential to generate earthquakes of magnitude 7.5 and higher. Thus, the whole island is considered to be a high seismic risk region. In the past 100 years, several earthquakes have affected both parts of the island. In the case of the Dominican Republic, two earthquakes stand out: a magnitude 8.1 earthquake on August 4, 1946, north of the Samaná Province, which caused a tsunami, soil liquefaction, and the loss of about 100 lives, and a magnitude 6.5 earthquake on September 22, 2003, in the city of Puerto Plata, which caused significant damage for infrastructures. Among the observed effects, the partial and total collapse of several school buildings had a remarkable impact on local communities. In addition to the high seismic risk, a large part of the national infrastructure may exhibit high vulnerability to earthquakes because the seismic regulations had been the same for 32 years, namely from 1979 to 2011. During these three decades, thousands of structures were built nationwide, including essential facilities such as hospitals and schools. Considering that the current student population in public schools in the Dominican Republic is over 2 million, with the majority attending buildings that were designed with the 1979 seismic code and which proved to be highly vulnerable during the Puerto Plata earthquake, it is vital to take measures that reduce the risk and minimize potential earthquake damage to school buildings. In this context, the Technological Institute of Santo Domingo (INTEC) has undertaken recently a project with the main objective to assess the seismic vulnerability of 22 schools located in the San Cristóbal Province, in the south of the Dominican Republic. The latter schools were all built prior to the adoption of the current updated seismic code. This paper presents the results of the assessment of the Fernando Cabral Ortega School. Although only the results of a single RC building are presented, the response of such structure can be considered representative of a portfolio of existing schools in Dominican Republic.
\end{abstract}

Keywords Seismic risk analysis $\cdot$ Seismic vulnerability $\cdot$ Existing structures $\cdot$ School $\cdot$ Dominican Republic

Communicated by Massimo Squillante.

L. Di Sarno

ldisarno@unisannio.it; Luigi.di-sarno@liv.ac.uk

N. J. Rojas-Mercedes

norberto.rojas@intec.edu.do

A. L. Simonelli

alsimone@unisannio.it

A. Penna

apenna@unisannio.it

1 Instituto Tecnológico de Santo Domingo (INTEC), Santo Domingo, Dominican Republic
2 Department of Civil Engineering and Industrial Design, School of Engineering, University of Liverpool, Liverpool, UK

3 Department of Engineering, University of Sannio, Benevento, Italy 


\section{Introduction}

The island of Hispaniola, shared by the Dominican Republic and Haiti (Fig. 1), is located in a subduction zone between the North America plate and the Caribbean plate. There are 13 geological faults in the interior of the island (Fig. 2), some of which have shown the potential to generate earthquakes of magnitude 7.0 and higher (Delanoy 1995; O' Reilly et al. 2004). Thus, the whole island is considered to be a high seismic risk region (De León 2005). In the past 100 years, several earthquakes have affected both parts of the island (Table 1). In the case of the Dominican Republic, two earthquakes have occurred in the last decades: a magnitude 8.1 earthquake on August 4, 1946, north of the Samaná Province, which caused a tsunami, soil liquefaction, and the loss of about 100 lives; and a magnitude 6.5 earthquake on September 22, 2003, which occurred around midnight in the city of Puerto Plata, causing great damages in infrastructure (Almeida 2011). Among the observed effects, the partial and total collapse of several school buildings stands out (López and Martínez 2003).

Within the affected school buildings can be mentioned La Reforma School which experienced the collapse of the first floor level (Fig. 3a) and the partial collapse of its roof slab (Fig. 3b); José Dubeau High School, with the complete collapse of a two-level annex (Fig. 3c); and the San Marcos School in which several columns were affected by the short column effect.

Also, damage in schools not only occurred in the city of Puerto Plata. According to a post-earthquake assessment carried out by the northern region of the Dominican College of Engineers, Architects and Surveyors (aka CODIA, Spanish Acronym), 44 schools experienced structural and non-structural damage in the city of Santiago (CODIA 2003). However, despite of the observed damage, only the

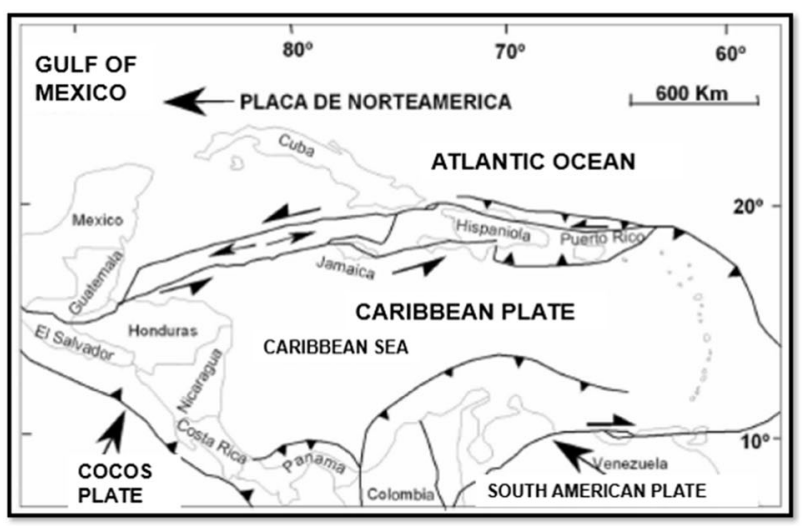

(a)

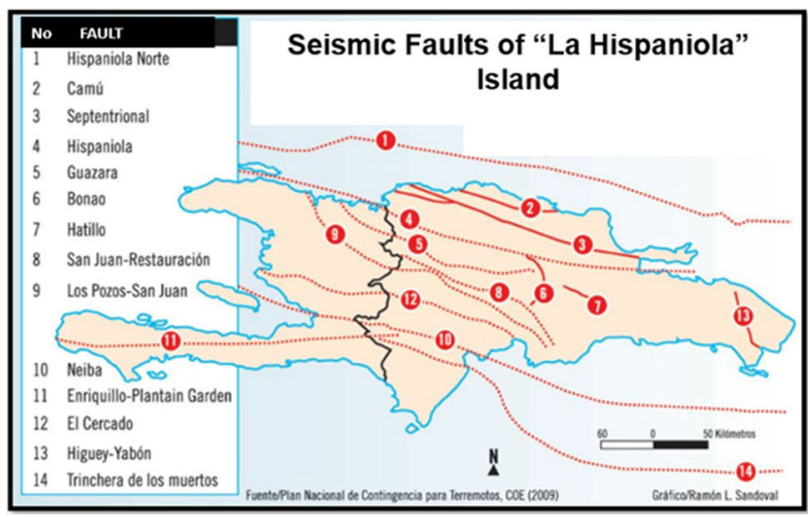

(b)

Fig. 2 a Tectonic plate locations and $\mathbf{b}$ seismic faults in the Hispaniola Island. Adapted from (COE 2009)

death of a person who was staying overnight in a motel that collapsed was recorded (Almeida 2011). If the earthquake had occurred during the day, a great national tragedy could have happened, where the victims would have been counted by thousands.
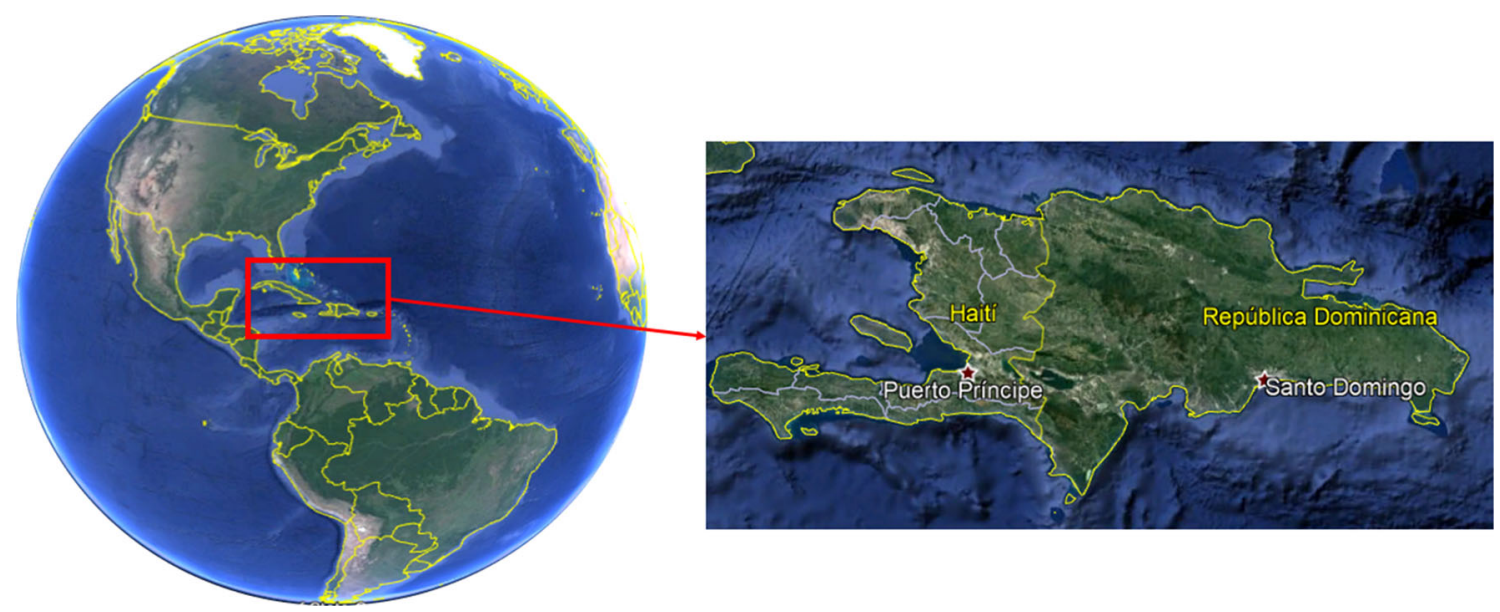

Fig. 1 Location of the Hispaniola Island. Image adopted from Google Earth 
Table 1 Seismic records of La Hispaniola Island from 1911 to 2010

\begin{tabular}{lll}
\hline Date & Magnitude (Richter scale) & Epicenter \\
\hline October 6, 1911 & 7.0 & Central Mountains \\
October 11, 1918 & 7.5 & Mona Passage \\
August 4, 1946 & 8.1 & Scotia Bay, Samana \\
January 8, 1962 & 6.5 & Central Mountains \\
March 23, 1979 & 6.1 & Higüey \\
June 24, 1984 & 6.7 & La Romana \\
September 22, 2003 & 6.5 & Puerto Plata \\
January 12, 2010 & 7.0 & Puerto Príncipe, Haiti \\
\hline
\end{tabular}

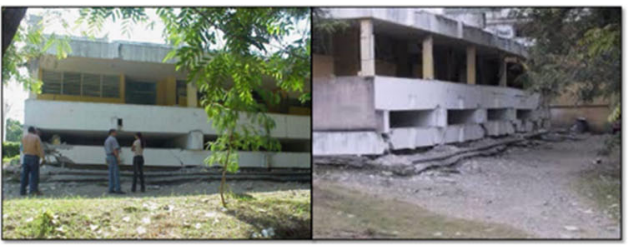

(a)

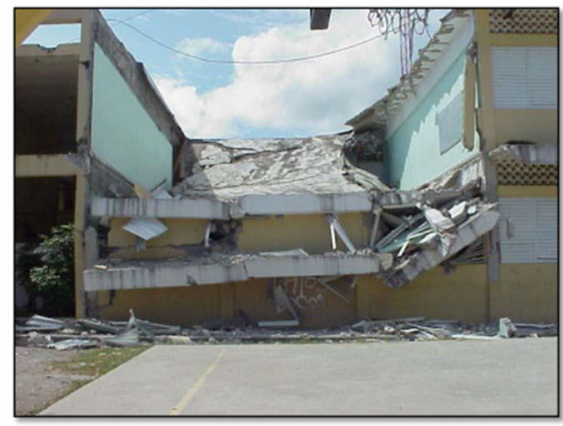

(c)

Fig. 3 Affected school buildings after the 6.5 Puerto Plata earthquake: La Reforma School: a collapse of the first floor level, $\mathbf{b}$ partial collapse of the roof slab and partial failure of the beam-column joint.

\section{Previous studies}

In the Latin American region, school buildings are of great importance since, in addition to teaching, they are used as shelters in the face of natural phenomena such as hurricanes and earthquakes. Such importance has been recognized by international organizations such as the Organization of American States (OAS), United Nations Educational, Scientific and Cultural Organization (UNESCO), and Educational Concerns for Hunger Organization (ECHO) which have financed projects focused on the reduction in vulnerability of school buildings in several Latin American countries such as Mexico (Gómez 1987), Ecuador (Argudo et al. 1992), and through the Program for the Reduction of the Vulnerability of the Education Sector to Natural Hazards (PRVSEPN, Spanish Acronym) (OEA 1992), other countries such El Salvador, Nicaragua, Belize, Costa Rica, Guatemala, Honduras, and Panama (Wong et al. 1997).

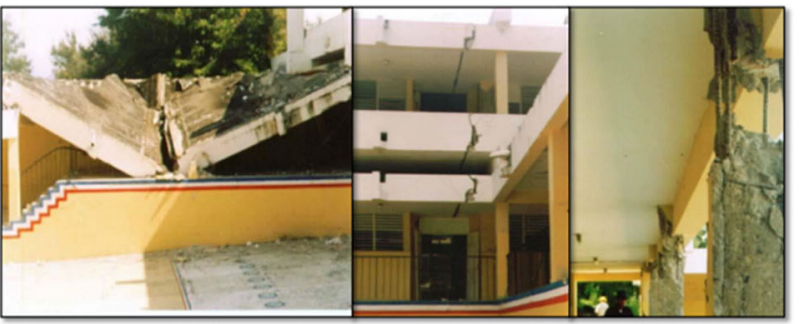

(b)

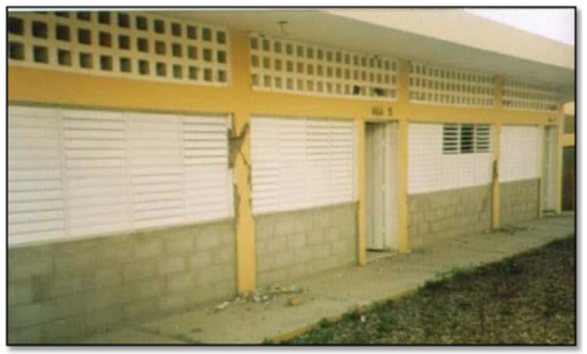

(d)

José Dubeau High School: c complete collapse of the school annex. And San Marcos School: d several columns were affected by the short column effect

Additionally, the evaluation of structural vulnerability of school buildings has focused the attention of researchers worldwide and hundreds of studies have been carried out around the world in terms of earthquake damage reports and vulnerability assessments of school buildings (Rodgers 2012). One of the countries in which more research has been conducted in last decades is Italy, since several earthquakes have strongly affected the school buildings recently and extensive damage has been observed in such structures (L'Aquila 2009: EEFIT 2009; EERI 2009; Molise 2002: Augenti et al. 2004). In the last decade, some of the conducted research has been focused in the assessment of damaged school buildings by means of qualitative method (Formisano 2012); the evaluation of retrofit schemes (Formisano et al. 2017) and the use of detailed advance numerical modeling techniques (Maracchini et al. 2017 and O' Reilly et al. 2019). Formisano (2012) assessed qualitatively 15 school buildings located in several municipalities of San Pietro, Italy, that were affected by the 
earthquake occurred on May 20, 2012. The results of the study indicated that all the evaluated structures showed structural schemes and constructive details that did not comply with the current Italian seismic code. It is recommended to retrofit such structures using simple schemes such as the casing of masonry walls with steel plates, as well as the use of tie beams to improve the connection between the walls, among others. Likewise, Formisano et al. (2017) examined the seismic performance of a retrofitted existing reinforced concrete school building, located in Naples, Italy. Such structure was composed by several modules and was designed for gravity load only. One of the modules was retrofitted with different techniques, with the objective of assess the behavior of each technique and select the best one in terms of economic, structural, and environmental point of view. It was found that the best retrofit solution was the buckling-restrained braces. The influence of different modeling choices and material properties uncertainties on the seismic assessment of an existing RC school building was evaluated by Maracchini et al. (2017). The authors found that mechanical properties of concrete and steel strongly affect the seismic risk index. Also, the authors pointed out that the concrete columns' mechanical properties have large impact on the seismic response of the building. Likewise, O' Reilly et al. (2019) assessed the behavior of four typical school structures in Italy, applying some of the most up-todate guidelines for the evaluation of seismic performance of structures. The evaluation included the development of detailed numerical models and the use of sophisticated analysis tools, which included an incremental dynamic analysis. The models were validated and calibrated from the results obtained from the measurement of ambient vibrations. From the results of their evaluation, the authors recommend to practitioners' engineers take care of their structural models to ensure that such models can represent the entire response of interest.

In the case of the Dominican Republic, the first and most complete seismic vulnerability evaluation project of school structures was carried out by the National Office of Seismic Evaluation and Vulnerability of Infrastructure and Buildings (ONESVIE, Spanish Acronym) (ONESVIE 2014) with the participation of other institutions such as the National Geological Service (SGN, Spanish Acronym), the offices of the Risk Management Program and the Education Regional of the Ministry of Education (MINERD, Spanish Acronym) and was sponsored by the Japan International Cooperating Agency (JICA). The main objective of this project was the qualitative evaluation of the structural vulnerability of schools in the San Cristóbal Province. A total of 320 schools were assessed, using an adaptation of the rapid visual detection method (FEMA 2002a, b) together with other evaluation methodologies (Lew et al.
2002; AGIES 2001). The project also included the classification of the structures according to their vulnerability index (Benedetti and Petrini 1984) which takes into account aspects of structural type, structural configuration, location of the building, foundations and non-structural elements. The results indicated that 290 schools $(90.7 \%)$ require a detailed structural evaluation. Likewise, the assessment of the vulnerability index showed that 53 schools $(16.56 \%)$ have a high vulnerability index; 243 schools $(75.94 \%)$ have an average vulnerability index and 24 schools $(7.5 \%)$ have a low vulnerability index. The authors recommended a detailed evaluation of the buildings that resulted with a high vulnerability degree.

\section{Objectives and scope of the ONESVIE project}

Vulnerability studies using qualitative methods constitute a first stage of evaluation when there are a large number of structures to be evaluated and limited resources are available. However, in order to make recommendations for reinforcement, a more detailed analysis is necessary, which was not contemplated within the objectives of the ONESVIE school evaluation project. Therefore, the aforementioned study should be completed in a second stage that includes the quantitative evaluation of each of the schools that resulted with a high degree of vulnerability and that proposes particular solutions based on the results of the analyzes of each one of the assessed schools.

Considering that the current student population in public schools in the Dominican Republic is over 2 million, with the majority attending buildings that were designed with the former 1979 seismic code and which proved to be very vulnerable during the Puerto Plata earthquake, it is deemed vital to take measures that reduce the risk and minimize potential earthquake damage to these structures. In this context, the Technological Institute of Santo Domingo (INTEC) has recently undertaken a project aimed at assessing the seismic vulnerability of 22 schools located in the San Cristóbal Province, in the south of the Dominican Republic. The case study schools were all built prior to the adoption of the current seismic code, which resulted in a higher degree of vulnerability according the study carried out by ONESVIE. The specific objectives established in order to achieve the main objective of this project are: (a) to determine whether the schools are adequate according to the current Dominican seismic code (2011); (b) to update structurally schools that do not comply with the Dominican seismic code and provide the structural solutions if necessary. 


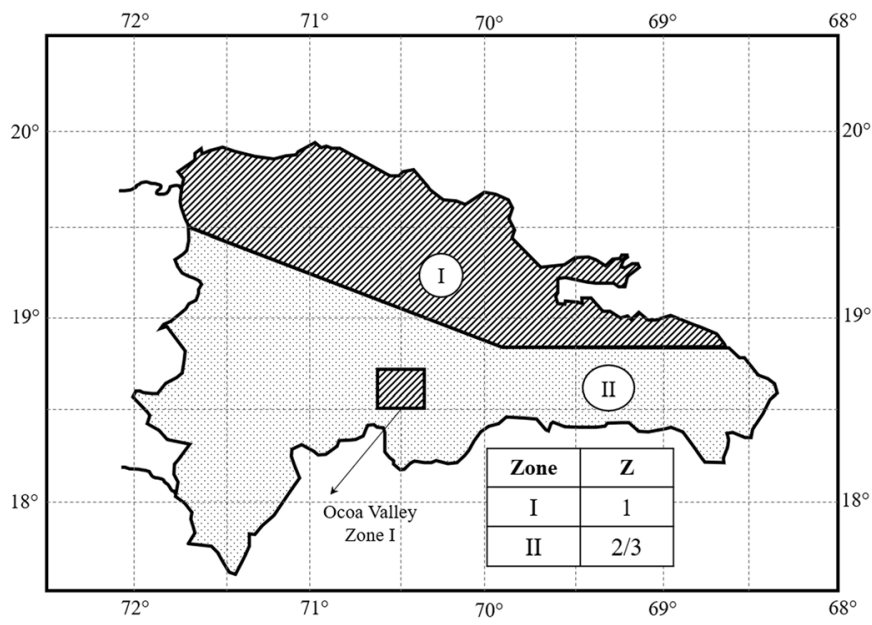

\section{Elastic Design Spectrum}

$\mathrm{C}=\frac{0.4}{\mathrm{~T}^{2 / 3}} \quad$ For $\mathrm{T}>0.5$ Secs.

$\mathrm{C}=0.635 \quad$ For $\mathrm{T} \leq 0.5$ Secs.

Inelastic Design Spectrum

$$
C_{b}=\frac{\text { ZUSC }}{R_{d}}
$$

\section{Where:}

$U=$ Use Coefficient

$\mathrm{S}=$ Site Coefficient

$\mathrm{Z}=$ Seismic Zone Coefficient

$\mathrm{Rd}=$ Energy Dissipation Factor Coefficient

Fig. 4 Elastic and inelastic design spectrum according to the 1979 Dominican seismic code. Adapted from (SEOPC 1979)
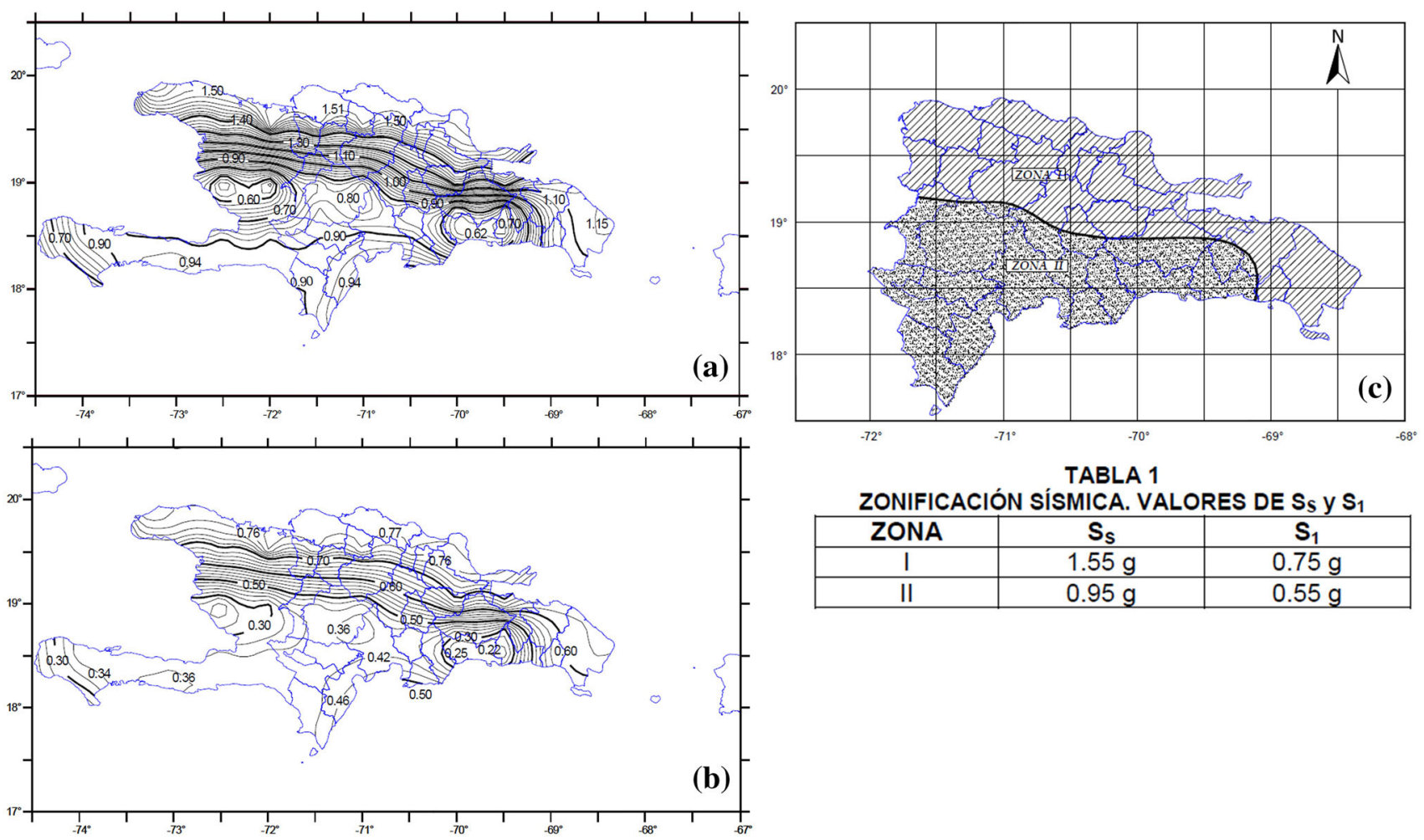

Fig. 5 Accelerations contour maps for a probability of exceedance of $2 \%$ in 50 years, according to the Dominican Republic 2011 seismic provisions. a Short period $\left(S_{\mathrm{S}}\right)$, b long period $\left(S_{1}\right)$, and $\mathbf{c}$ seismic zoning. Adapted from MOPC (2011)

\section{Code practice in the Dominican Republic}

In the Dominican Republic, prior to the implementation of the current seismic design code (MOPC 2019) what existed were some recommendations that governed the seismic design dating back from 1979 (O' Reilly 2002). That implies the country had the same seismic regulations for 32 years. During these three decades, thousands of structures (including schools) were built throughout the national territory that may be vulnerable to a seismic event. Following sections briefly discuss the main features of both the 1979 Seismic Code Provisional Recommendations and the current Seismic Code implemented in 2011, as well as two important seismic hazards studies carried out in both sides of the Hispaniola Island. 
Fig. 6 Elastic and inelastic design spectrum expressions as per R-001 seismic code. Adapted from MOPC (2011)

\section{Elastic Design Spectrum}

$$
\begin{array}{lll}
S a=0.6 \frac{S_{D S}}{T o} *(T)+0.4 S_{D S} & \text { For } & T \leq T_{0} \\
S a=S_{D S} & \text { For } & T_{0}<T \leq T s \\
S a=\frac{S_{D 1}}{T} & \text { For } T>T s
\end{array}
$$

Where:

$$
\begin{array}{ll}
\mathrm{S}_{\mathrm{DS}}=2 / 3 \mathrm{Fa} \cdot \mathrm{Ss} & T_{0}=0.2 * \frac{S_{D 1}}{S_{D S}} \\
\mathrm{~S}_{\mathrm{D} 1}=2 / 3 \mathrm{Fv} \cdot \mathrm{S}_{1} & T_{S}=5 T_{0}
\end{array}
$$

\section{Inelastic Design Spectrum}

$$
C b=\frac{U^{*} S a}{R d} \geq 0.03
$$

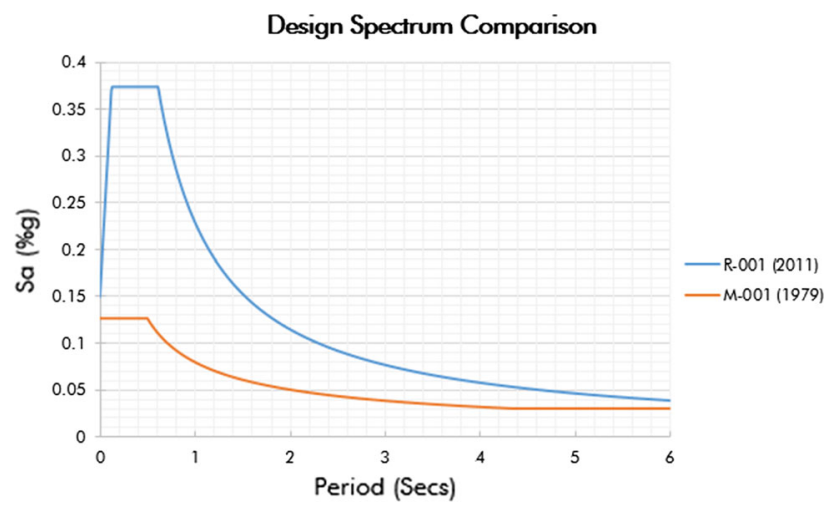

Fig. 7 Design spectrum comparison for the San Cristobal Province

\subsection{9 provisional recommendations for the seismic analysis of structure}

The provisional recommendations for the seismic analysis of structures (SEOPC 1979) divide the country into two seismic zones: (1) high seismicity and (2) medium seismicity zone, as shown in Fig. 4. The design spectra, both elastic and inelastic, are shown in the same figure. It is important to mention that the $U-, S-$, and $R_{\mathrm{d}}$-coefficients are tabulated values that depend on the importance of the structure, the site in which the structure is located, and the type of structural system, respectively.

\subsection{Regulations for the seismic analysis and design of structures R-001}

The regulation for the seismic analysis and design of structures (MOPC 2011) is basically an adaptation of the ASCE7-05 code (ASCE 2005) of the USA. For the purposes of the regulation, the Dominican Republic is divided into two zones, according to their reference spectral seismic acceleration levels $S_{\mathrm{S}}$, for a return period of 2475 years, with a probability of exceeding $2 \%$ in 50 years. Alternatively, for design purposes, the use of spectral iso-acceleration maps is allowed for short periods $\left(S_{\mathrm{S}}\right)$ and long periods $\left(S_{1}\right)$, as shown in Fig. 5. The code also provides accelerations contour maps for both $2 \%$ and $10 \%$ probabilities of exceedance in 50 years. The expressions that define the elastic design spectrum are shown in Fig. 6. In the figure, $F_{\mathrm{a}}$ and $F_{\mathrm{v}}$ are the site coefficients, which depend on the site classification. Likewise, $U$ represents the use of the structure, means while $R_{\mathrm{d}}$ is the energy dissipation factor that is a function of the structural system. It is important to mention that the current seismic code is not intended for the evaluation of existing structures; thus, the evaluation of the seismic risk of as-built schools may become controversial, especially for the estimation of the hazard levels.

The comparison of the design spectra by both the 1979 and 2011 codes for a concrete frame school structure located in the San Cristóbal Province is shown in Fig. 7. Considering that, as first estimate, the fundamental period for a reinforced concrete (RC) frame structure can be evaluated as $0.1 \mathrm{~N}$, where $N$ is the number of levels of the structure, for a typical school building of three levels, the seismic forces obtained from the 1979 code could underestimate such load in $61 \%$ (Table 2). Thus, it is necessary that school buildings designed with the former provisional regulations need to be assessed in order to determine the degree of vulnerability that such structures pose.

\subsection{Seismic hazard maps for Haiti}

After the devastating earthquake (magnitude 7.0) of January 12, 2010 that occurred in Haiti, a group of researchers 
Table 2 Comparison of the 1979 (M-001) and the 2011 (R001) spectral accelerations

\begin{tabular}{lllll}
\hline Period $(\mathrm{s})$ & Sa $(\% \mathrm{~g}) \mathrm{M}-001$ & Sa $(\% \mathrm{~g})$ R-001 & Difference & Difference $(\%)$ \\
\hline 0 & 0.127 & 0.149 & 0.02 & 18 \\
0.01 & 0.127 & 0.168 & 0.04 & 32 \\
0.02 & 0.127 & 0.186 & 0.06 & 46 \\
0.03 & 0.127 & 0.204 & 0.08 & 61 \\
\hline
\end{tabular}

PGA $(\% g)$ with $10 \%$ Probability of Exceedance in 50 Years

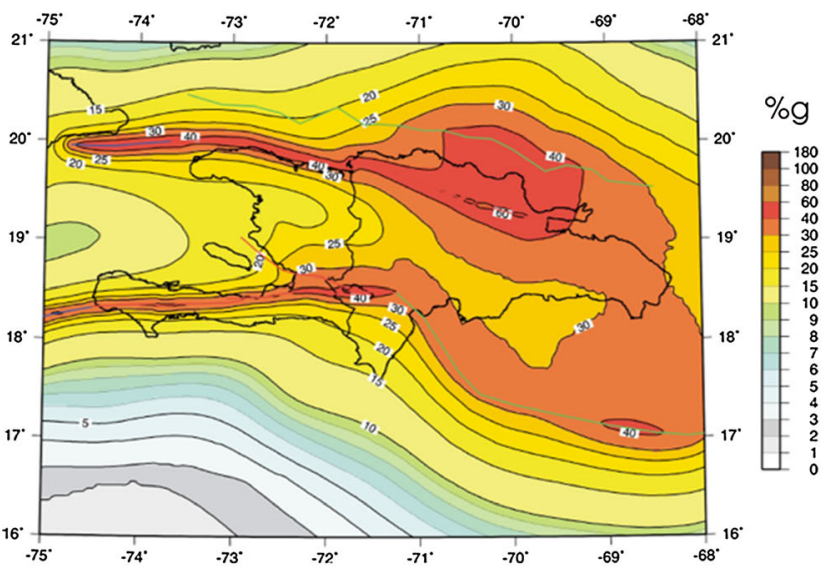

(a)
PGA (\%g) with $2 \%$ Probability of Exceedance in 50 Years

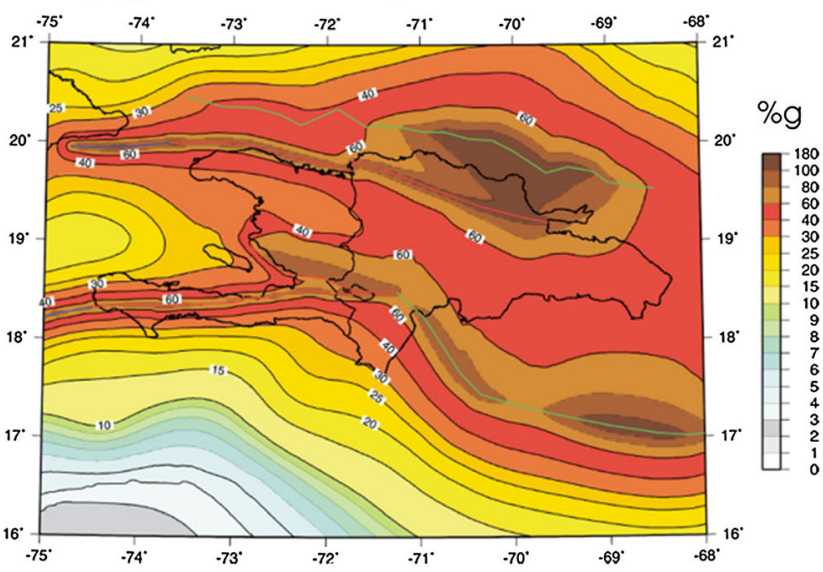

(b)

Fig. 8 Seismic hazard map of Hispaniola region with peak ground acceleration (PGA; in \%g) a $10 \%$ probability of exceedance in 50 years and b $2 \%$ probability of exceedance in 50 years. Adapted from Frankel et al. (2011)

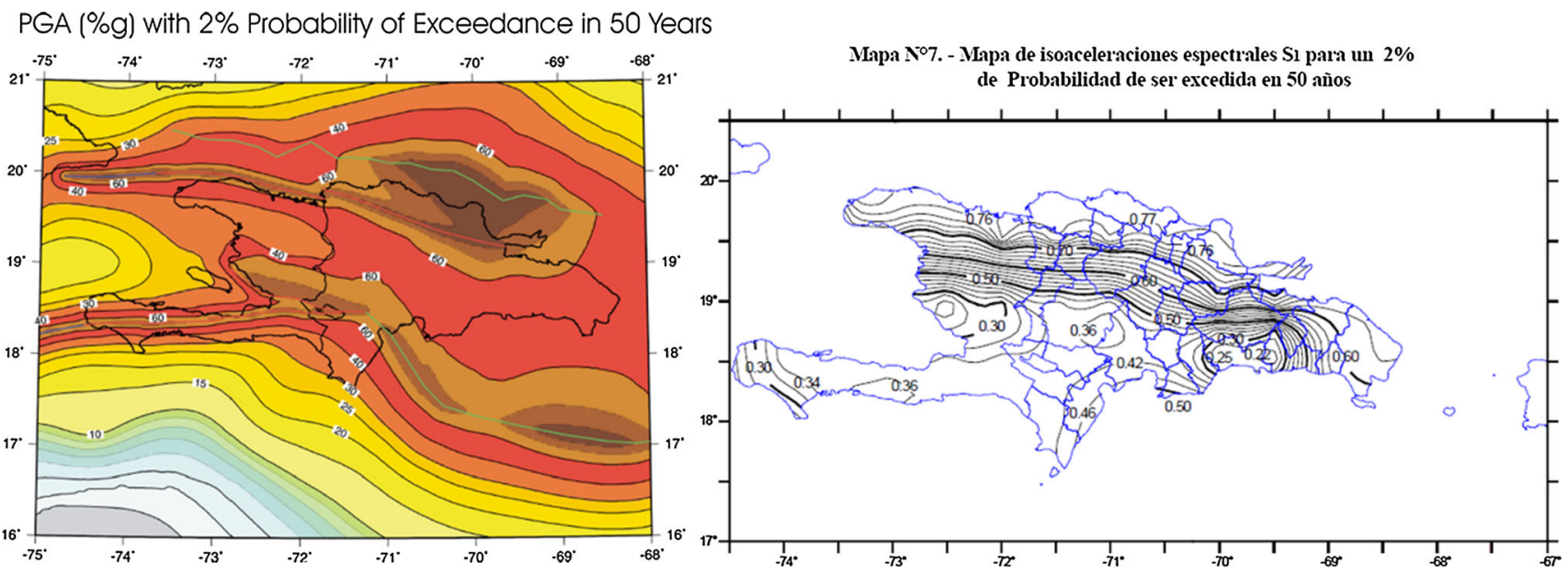

Fig. 9 Comparison between the contour accelerations of the seismic hazard maps developed by Frankel et al. (2011) and the long-period spectral accelerations $\left(S_{1}\right)$ indicated in the R-001 seismic code, for the $2 \%$ probability of exceedance in 50 years

led by the United States Geological Survey (USGS) constructed probabilistic seismic risk maps for Haiti in order that serve as the basis for the development of building codes and standards in that country (Frankel et al. 2011). Although the maps were developed for the entire island of Hispaniola, the authors indicate that they cannot be considered as complete hazard maps for the Dominican Republic since they do not take into account all the sources of earthquake hazard that affect the eastern of the Hispaniola. The proposed maps are depicted in Fig. 8 .

According to FEMA 451 (reference), the values of the long-period accelerations $\left(S_{1}\right)$ and the short-period accelerations $\left(S_{\mathrm{S}}\right)$ can be estimated from the PGA. In that regards, $S_{1}$ can be taken equal to the PGA and $S_{\mathrm{S}}$ as 2.5 times the PGA. Thus, it is possible to relate the accelerations proposed in the R-001 seismic code with the ones 
PGA $(\% g)$ with $2 \%$ Probability of Exceedance in 50 Years
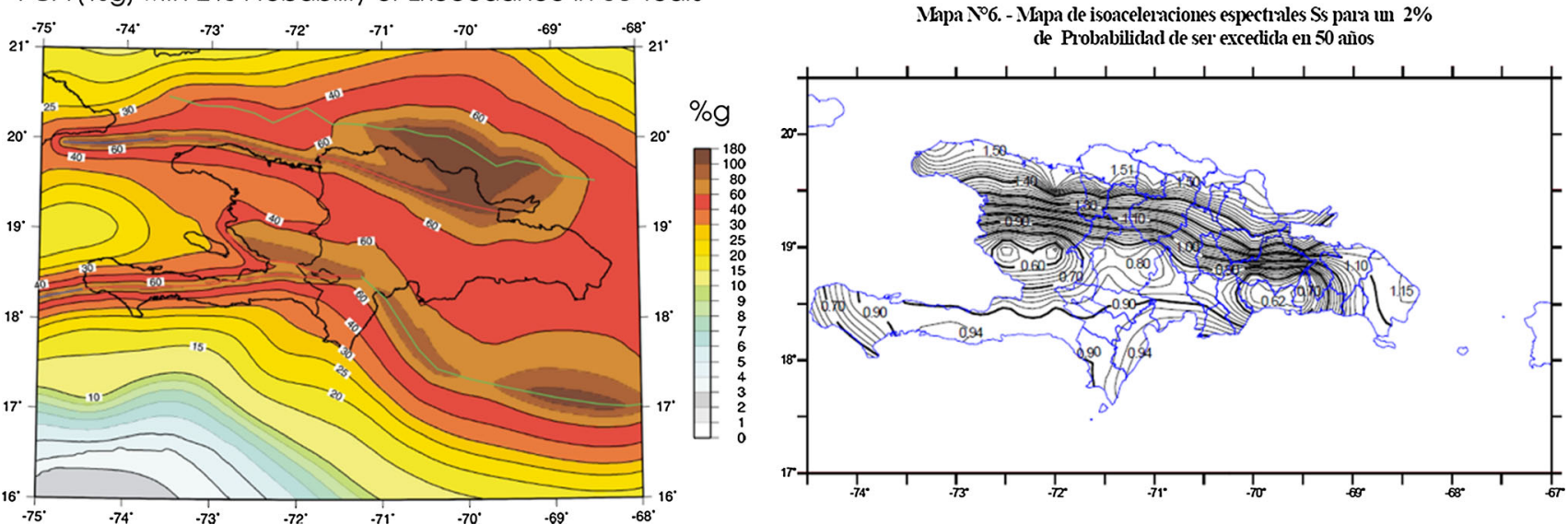

Fig. 10 Comparison between the contour accelerations of the seismic hazard maps developed by Frankel et al. (2011) and the short-period spectral accelerations $\left(S_{\mathrm{s}}\right)$ indicated in the R-001 seismic code, for the $2 \%$ probability of exceedance in 50 years

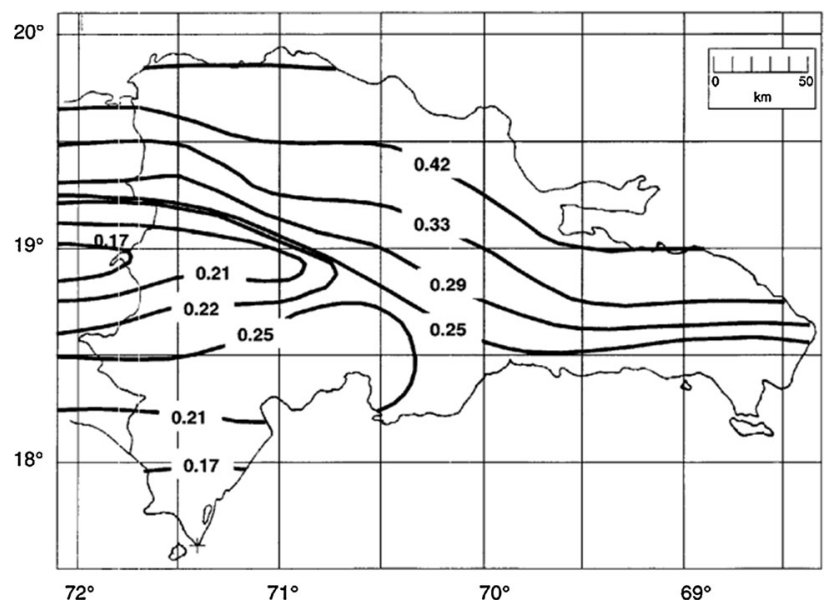

Fig. 11 Peak ground acceleration (PGA) contours (10\% probability of exceedance in 50 years) proposed by Lew et al. (2002)

developed by Frankel et al. (2011). The comparison for the case of the long-period spectral acceleration is shown in Fig. 9. It is observed that the current seismic code has higher accelerations around the northern fault (northwest and northeast of the Dominican Republic). However, outside this region, the acceleration contour proposed by Frankel et al. (2011) shows higher accelerations. The same conclusions apply for the case of the short-period spectral acceleration (Fig. 10).

\subsection{Seismic and windstorm evaluation of existing RC buildings for the Dominican Republic}

As part of a reconstruction project funded by the United States Agency for International Development (AID), the National Institute of Standard Technology (NIST) (Lew et al. 2002) developed a manual to evaluate critical reinforced concrete structures (hospitals, emergency response centers, etc.). Such manual was based on the procedures described in two documents published by the Federal Emergency Management Agency FEMA (FEMA 178 1992; FEMA 310 1998). In this document, the seismic load for the evaluation of existing structures (since some level of damage is acceptable in an existing structure) is obtained from recommended PGA values proposed in this study based on an estimate of $10 \%$ probability in 50 years (Fig. 11).

\section{Methodology}

The methodology implemented in the study presented in the previous section is summarized as follows:

- Schools selection;

- Architectural survey;

- Structural survey;

- Structural modeling;

- Recommendations.

The above framework fulfills the current practice for seismic assessment of existing RC buildings also in the earthquake-prone regions in the south of Europe (e.g., Di Sarno and Manfredi 2010, 2012, among others). The details of each of the above-mentioned steps are presented in the following sections.

\subsection{Schools selection}

To ensure that the selected schools are the most critical, they must meet the following selection criteria:

- The structure's material must be reinforced concrete;

- Have two or more storeys; 
- Have a medium to high vulnerability index [from the ONESVIE study (ONESVIE 2014)];

- The year of construction must be before 2011. (It is assumed that the structures built with the current code are not vulnerable.)

\subsection{Architectural survey}

Due to the low probability that architectural plans are available, it is proposed to perform an architectural survey to identify both the gravity and the lateral load resistance systems as well as to obtain the dimensions of the structural elements.

\subsection{Structural survey}

In accordance with the requirements for the evaluation of existing buildings (MOPC 2019) established by the Ministry of Public Works of the Dominican Republic (MOPC Spanish acronym), the structural survey for RC structures shall include the assessment of the structural member conditions, the evaluation of concrete strength of the structural components, as well as the evaluation of the reinforcement steel. In this document, the concrete strength shall be evaluated by means of destructive and/or nondestructive test, with the minimum number of sample testing established according to the following criteria:

(a) Destructive test a. $15 \%$ of the vertical earthquake-resistant structural components (walls and columns) in both $X$ - and $Y$-directions;

b. At least one core should be extracted each $15 \mathrm{~m}^{3}$ for beams;

c. At least one core should be extracted each $150 \mathrm{~m}^{2}$ for concrete slabs.

(b) Nondestructive test

a. $25 \%$ of the structural elements of each level, which must be complemented with core testing of at least $5 \%$ of the vertical earthquake-resistant elements; one core each $30 \mathrm{~m}^{3}$ for beams and one core each $300 \mathrm{~m}^{2}$ of concrete slabs.

For the case of the steel reinforcement, the minimum number of structural elements that must be verified is as follows: (a) $70 \%$ of the columns and structural walls, (b) $30 \%$ of the reinforced concrete beams, and (c) $10 \%$ of the reinforced concrete slabs.

The MOPC requirements also establish the evaluation of the foundation system by means of explorations that include: (a) concrete core samples in at least $10 \%$ of the foundations but not less than two samples and (b) the geometry of the section (foundation depth, slab thickness, and foundation area).

Due to budgetary constraints, it was not possible to reach the minimum number of concrete core samples as required by the MOPC. However, to obtain a representative concrete strength for modeling purposes, a minimum number of three sample tests were established by structural elements as suggested by FEMA $356(2000,2002)$. Such
Fig. 12 Fernando Cabral Ortega School
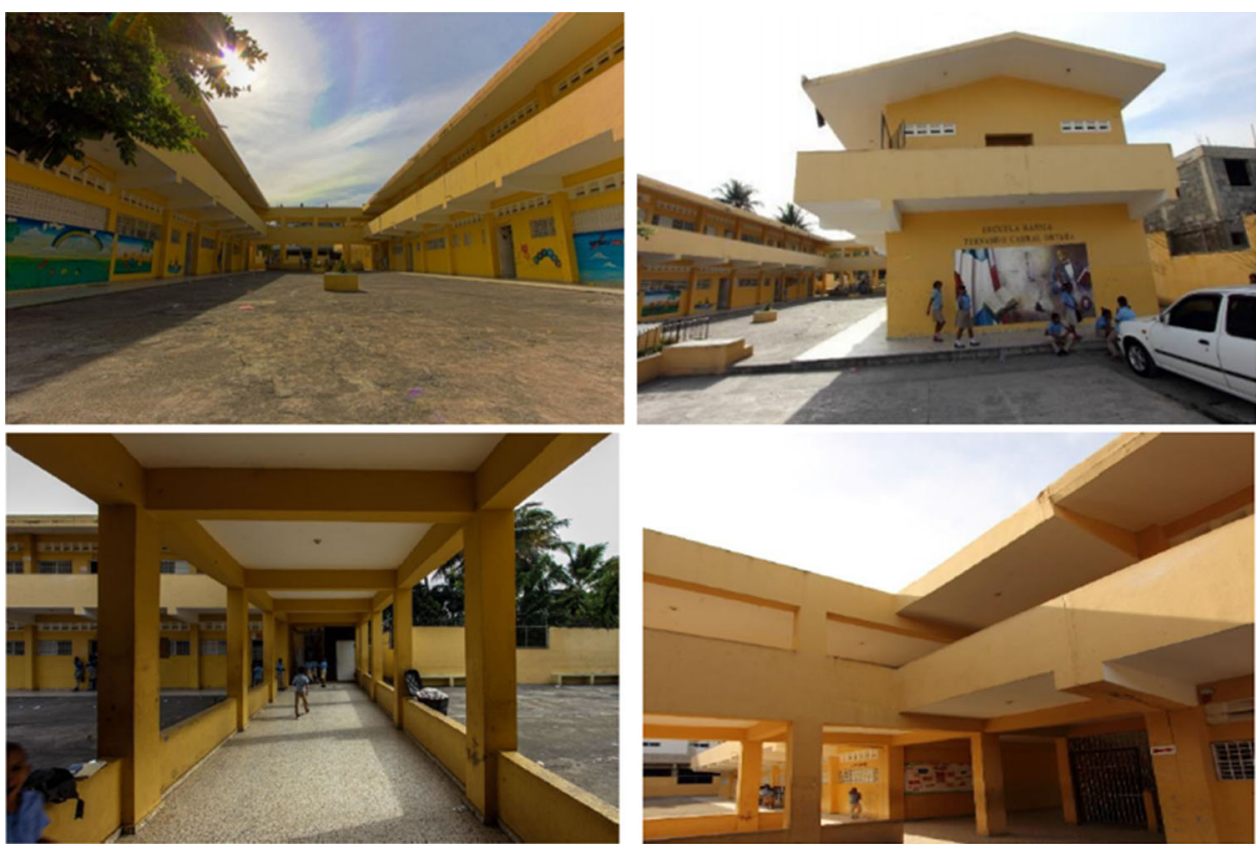


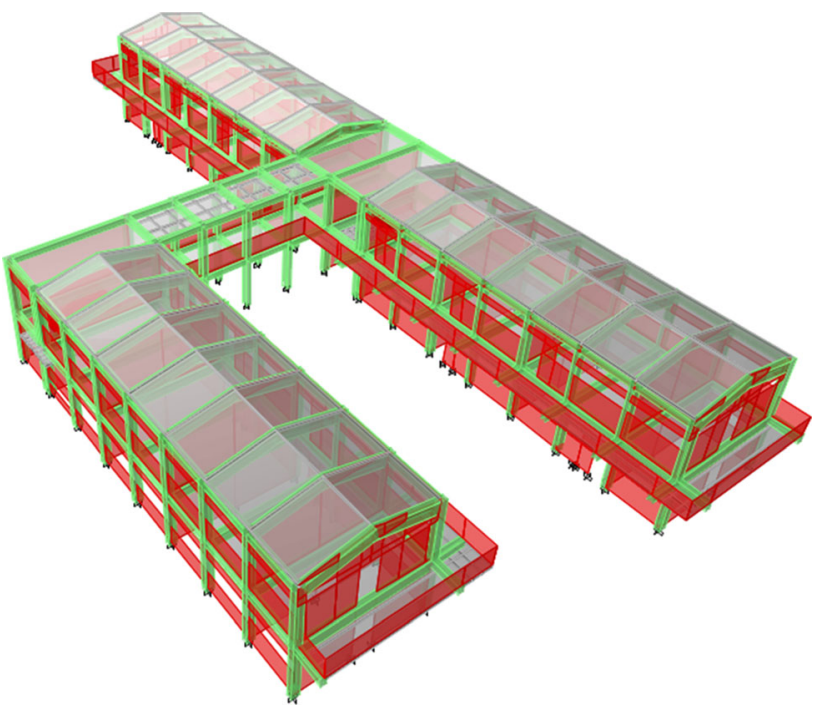

Fig. 13 Rendered view of the Fernando Ortega School

Fig. 14 Beam and column details

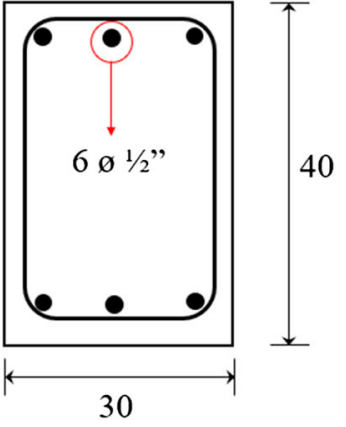

Y Direction

elements were selected based on a preliminary structural analysis. At the same time, for the same reasons, it was not possible to carry out the inspection of the foundations.

\subsection{Preliminary structural model}

To optimize the number of concrete samples, a preliminary structural model was implemented numerically with the main objective to identify those structural elements with the higher load demands that will be selected for a destructive-type test.

\subsection{Refined structural model}

With the properties of the concrete obtained from the structural assessment and the arrangement of the reinforcing bars in the structural elements determined from the scanning of such elements, a refined analysis model was

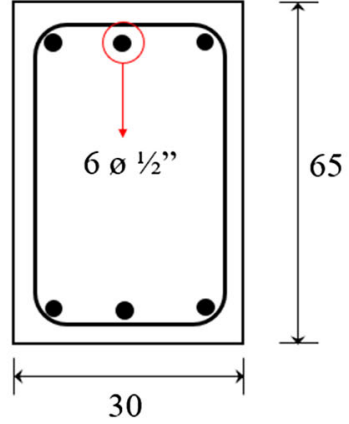

$\mathrm{X}$ Direction

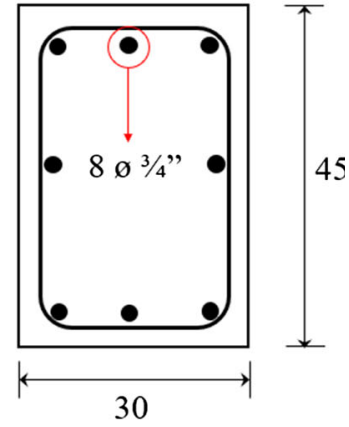

Column Detail

Beam Detail
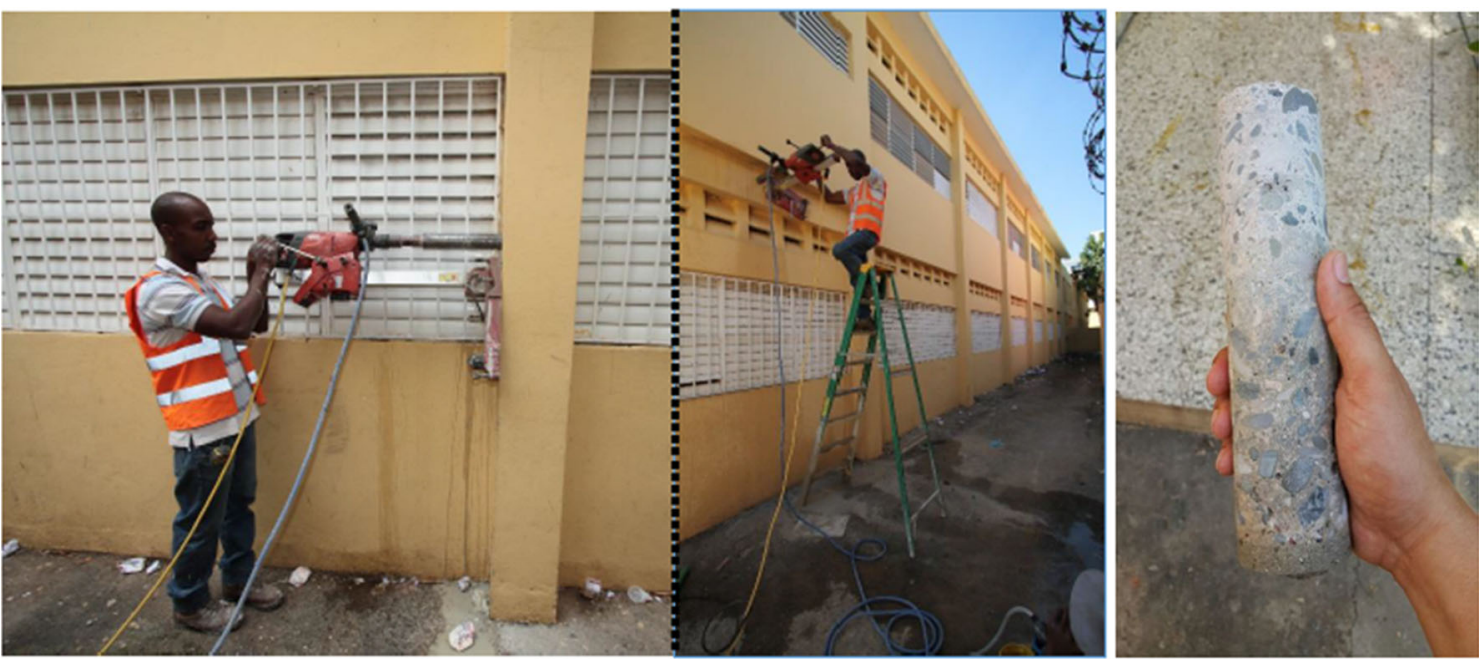

Fig. 15 Concrete core extraction 
Table 3 Concrete core test results for beams

\begin{tabular}{|c|c|c|c|c|c|c|c|c|c|}
\hline Sample ID & Building & Element type & Diameter $(\mathrm{cm})$ & Area $\left(\mathrm{cm}^{2}\right)$ & $L / D$ & Factor & Load test $(\mathrm{kg})$ & Stress test $\left(\mathrm{kg} / \mathrm{cm}^{2}\right)$ & Stress test $(\mathrm{MPa})$ \\
\hline N\#1 & 1 & Beam & 5.6 & 24.63 & 1.75 & 0.98 & 9384 & 381 & 37 \\
\hline \multirow[t]{4}{*}{$\mathrm{N \# 2}$} & 2 & Beam & 5.6 & 24.63 & 1.75 & 0.98 & 10,369 & 421 & 41 \\
\hline & & & & & & & Mean & 401 & 39 \\
\hline & & & & & & & Stdv & 20 & \\
\hline & & & & & & & $\mathrm{COV}$ & $5 \%$ & \\
\hline
\end{tabular}

Table 4 Concrete core test results for columns

\begin{tabular}{llllllllll}
\hline Sample ID & Building & Element type & Diameter $(\mathrm{cm})$ & Area $\left(\mathrm{cm}^{2}\right)$ & $L / D$ & Factor & Load test $(\mathrm{kg})$ & Stress test $\left(\mathrm{kg} / \mathrm{cm}^{2}\right)$ & Stress test $(\mathrm{MPa})$ \\
\hline N\#1 & 1 & Column & 5.6 & 24.63 & 1.75 & 0.98 & 5148 & 209 & 20 \\
N\#2 & 2 & Column & 5.6 & 24.63 & 1.75 & 098 & 3374 & 137 & 13 \\
N\#3 & 3 & Column & 5.6 & 24.63 & 1.75 & 0.98 & 4877 & 198 & 19 \\
& & & & & & & Mean & 181 & \\
& & & & & & & Stdv & 39 & \\
\end{tabular}

constructed which includes the seismic loads demands according to the current seismic regulations.

\subsection{Recommendations}

If the results of the structural analysis indicate that the building system does not comply with the requirements of the R-001 regulations, a structural solution will be proposed. This scheme will be evaluated through a static nonlinear analysis (pushover) and/or by means a time history analysis in order to determine the effectiveness of the proposed solution.

Next section shows the assessment of the Fernando Cabral Ortega School by applying the methodology previously described above. Although only the results of a single RC building are presented, the response of such structure can be considered representative of a portfolio of existing schools in Dominican Republic.

\section{Case study: the Fernando Cabral Ortega School}

The Fernando Cabral Ortega School is located in the community of La Jeringa, Municipality of San Cristóbal. The structure has a capacity for 400 students and was built in 1996. According to the School Vulnerability Report presented by ONESVIE, the structure resulted with a high vulnerability index. The structure consists of three building modules of two levels each connected by a corridor as shown in Figs. 12 and 13. The structural system is composed by RC frames in both directions enclosed by masonry walls. It can be noticed that the structures satisfy the established selection criteria.

\subsection{Architectural and structural survey}

The structural drawings of the sample building were not available; therefore, the cross-sectional dimensions of the elements, the concrete strength, and the reinforcement details were obtained from both the architectural and structural surveys, respectively. The cross sections of beams and columns are depicted in Fig. 14.

The concrete strength was assessed by means of destructive test. A total of six samples were evaluated

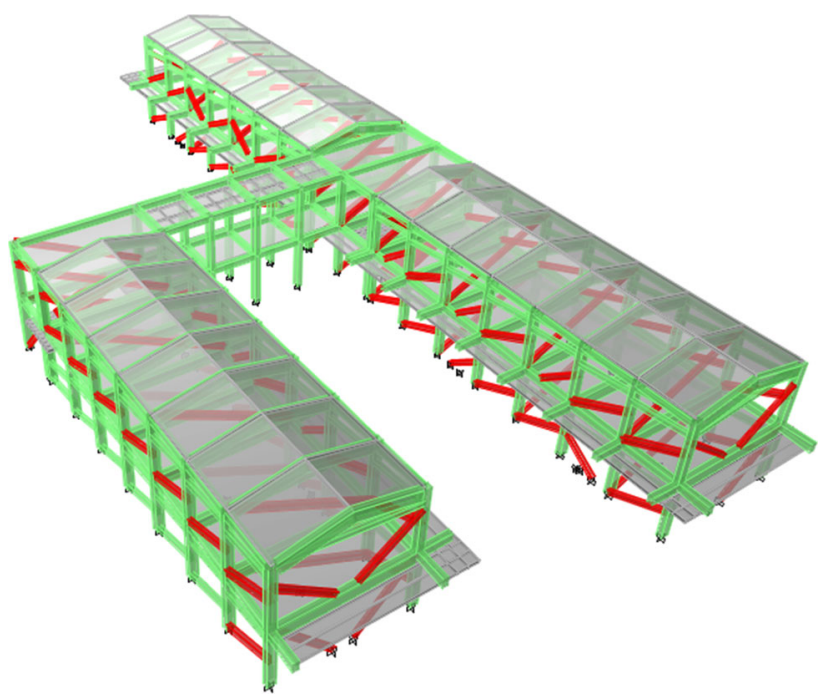

Fig. 16 Structural model 


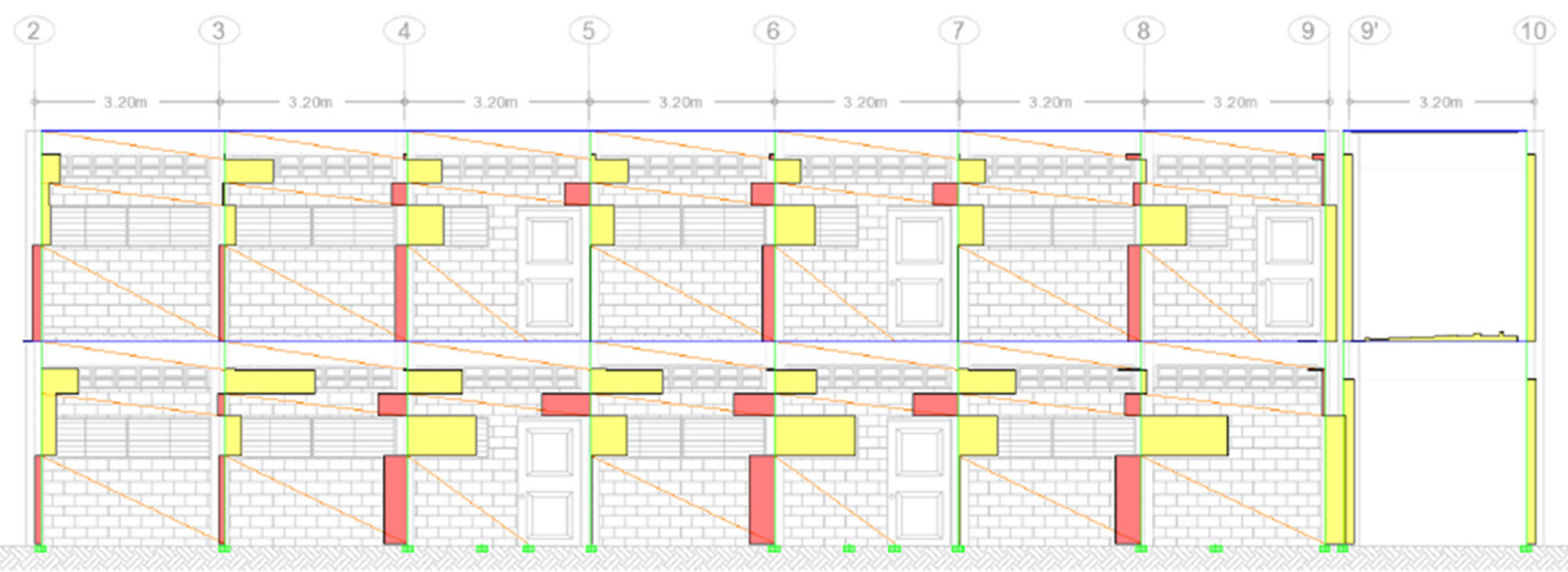

Fig. 17 Shear diagram in columns at the corridors

(three in beams and three in columns), in structural elements that resulted with higher load demand according to a preliminary structural analysis. The concrete core extraction process is shown in Fig. 15. The concrete test results for the beams and columns are shown in Tables 3 and 4, respectively. It is noteworthy to mention that three samples were extracted for the beams; however, the stress obtained from one of the tests was only $55 \mathrm{~kg} / \mathrm{cm}^{2}$ (5 MPa), which is clearly an outlier and thus was discarded.

Section 6.3.2.4.1 of FEMA 356 (FEMA 356) states that the minimum number of tests to determine any property is 3 but limited to a coefficient of variation less or equal to $14 \%$.

It can be seen in Table 3 that even though only two tests were evaluated, the coefficient of variation resulted below $14 \%$. For the case of the columns (Table 4), the coefficient of variation exceeded $14 \%$, which implies that more tests are needed. However, it was decided to use in both cases the average of the test results; thus, the concrete strength used in the calculations was set equal to $f_{\mathrm{c}}=39 \mathrm{MPa}$ for the beams and $f_{\mathrm{c}}^{\prime}=18 \mathrm{MPa}$ for the columns. For the case of the reinforcement steel yield strength, a value of $f_{\mathrm{y}-}$ $=280 \mathrm{MPa}$ was set, as indicated by the MOPC R-033 (MOPC 2012) when no information regarding reinforcement steel is available.

\subsection{Structural model}

In order to evaluate the behavior of the building structure, a numerical finite element model was created using the ETABS software (Computer and Structures 2005). Such model is shown in Fig. 16. Beams and columns were modeled according to the sections as depicted in Fig. 14. In both elements, the cracking effect as required by the R-001 was considered. To take into account, the effect of the masonry infill walls as an equivalent diagonal as suggested in section 7.5.2.1 of FEMA 356 was used. Both gravitational and seismic loads were estimated as per R-001 regulations. Although in the architectural survey, it was

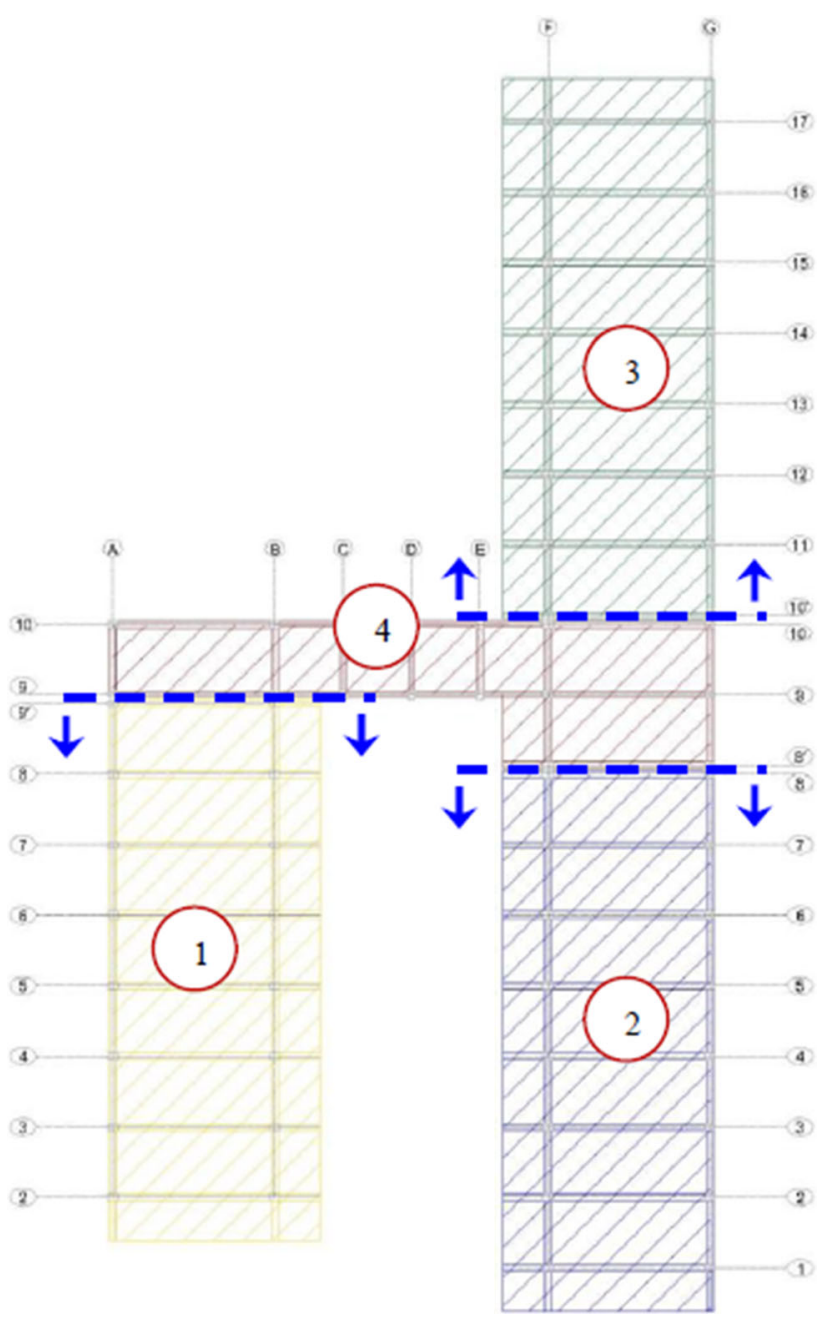

Fig. 18 Suggested construction joint 
Fig. 19 Masonry walls separation details

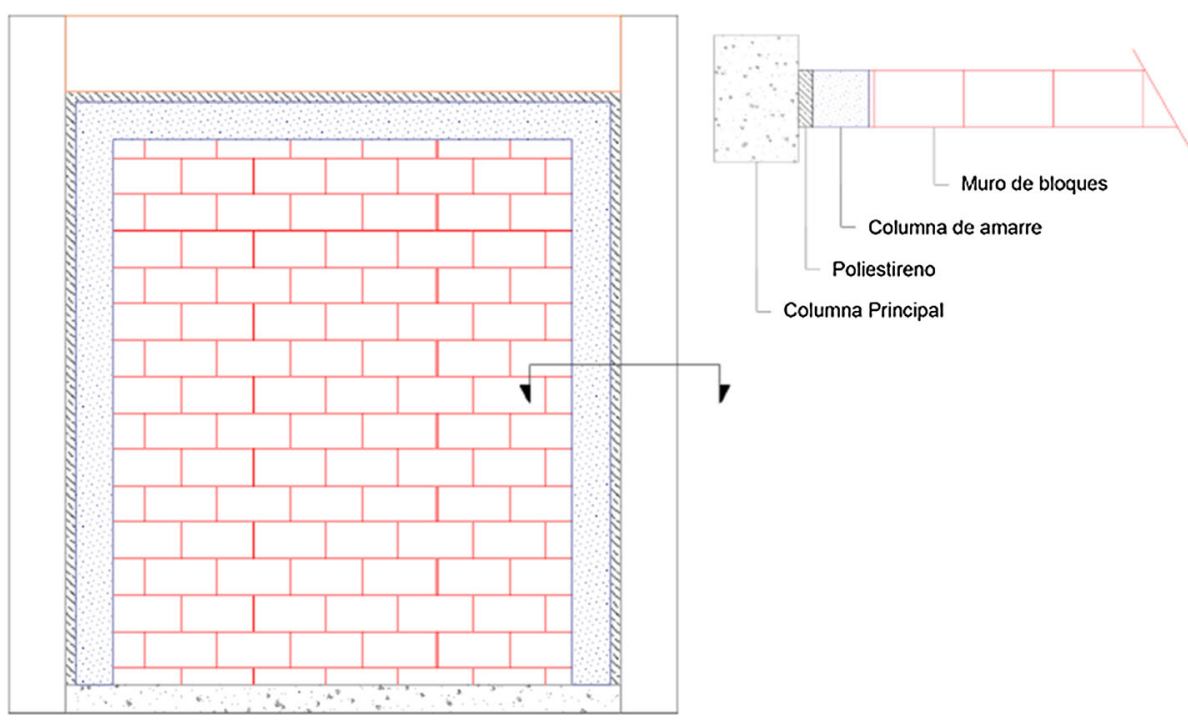

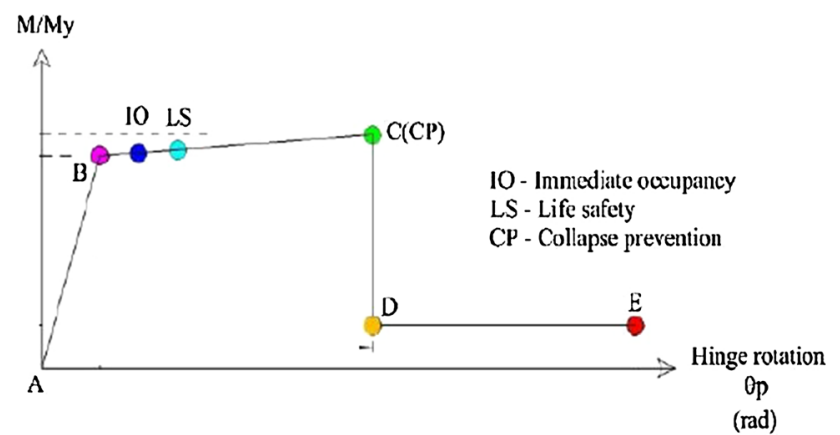

Fig. 20 Plastic hinge model for flexural member

identified that the structures are separated by construction joints, however, the slab was cast in place continuously, which makes it behave as one body instead of four.

\subsection{Results}

Based on the averages of the concrete strength obtained from destructive tests, the columns of the structures do not comply with Article 43 of R-033 Regulation (MOPC 2012), which requires that in structural elements, the minimum concrete strength should be $210 \mathrm{~kg} / \mathrm{cm}^{2}$ (21 MPa). Also, analysis results indicate that the structure has plan irregularity and thus does not comply with the Article 38 of the R-001 regarding excessive torsion. In addition, columns near the corridors are showing high shear demands due to the partial constraint imposed by the infill masonry walls (Fig. 17). As first solution, it was proposed: (1) separate the structure and model it as four independent structures (Fig. 18) and (2) uncouple masonry walls from the columns using the detail as shown in Fig. 19.

\subsubsection{Pushover analysis}

To evaluate the performance of the proposed modified structure, a nonlinear static analysis (pushover) was carried out. The properties of the plastic hinges for the beams and columns were defined according to the recommendations of the standard ASCE7-05 (ASCE 2005). The behavior of the plastic hinges (Fig. 20) was evaluated at the performance point of the structure, in terms of the rotations limits established by the ATC-40 (Applied Technology Council 1996) for buildings with special occupation. To these buildings corresponds an immediate occupancy (IO) level.

The pushover analysis results for the case of building I only are shown in Fig. 21 ( $X$-direction) and in Fig. 22 ( $Y$ direction). The results for the other buildings are not shown due to space constraints. It can be seen in these figures that all the columns of the first level reached the life safety limit state and thus do not satisfy the expected performance level for the structure. These results suggest that the structure must be reinforced. As a solution, it is proposed to reinforce the columns and beams of the structure with the detail as shown in Fig. 23.

In order to validate the behavior of the reinforced structure, a new analysis was performed. The results are shown in Fig. 24 ( $X$-direction) and in Fig. 24 ( $Y$-direction). It is noted that for the performance point, the plastic hinge is kept within the limits of immediate occupation. These results suggest that the proposed reinforcement is adequate.

\section{Conclusions}

The main conclusions that can be highlighted from this study are the following: 
Fig. 21 Plastic hinge behavior for pushover analysis in the $X$ direction
Fig. 22 Plastic hinge behavior for pushover analysis in the $Y$ direction
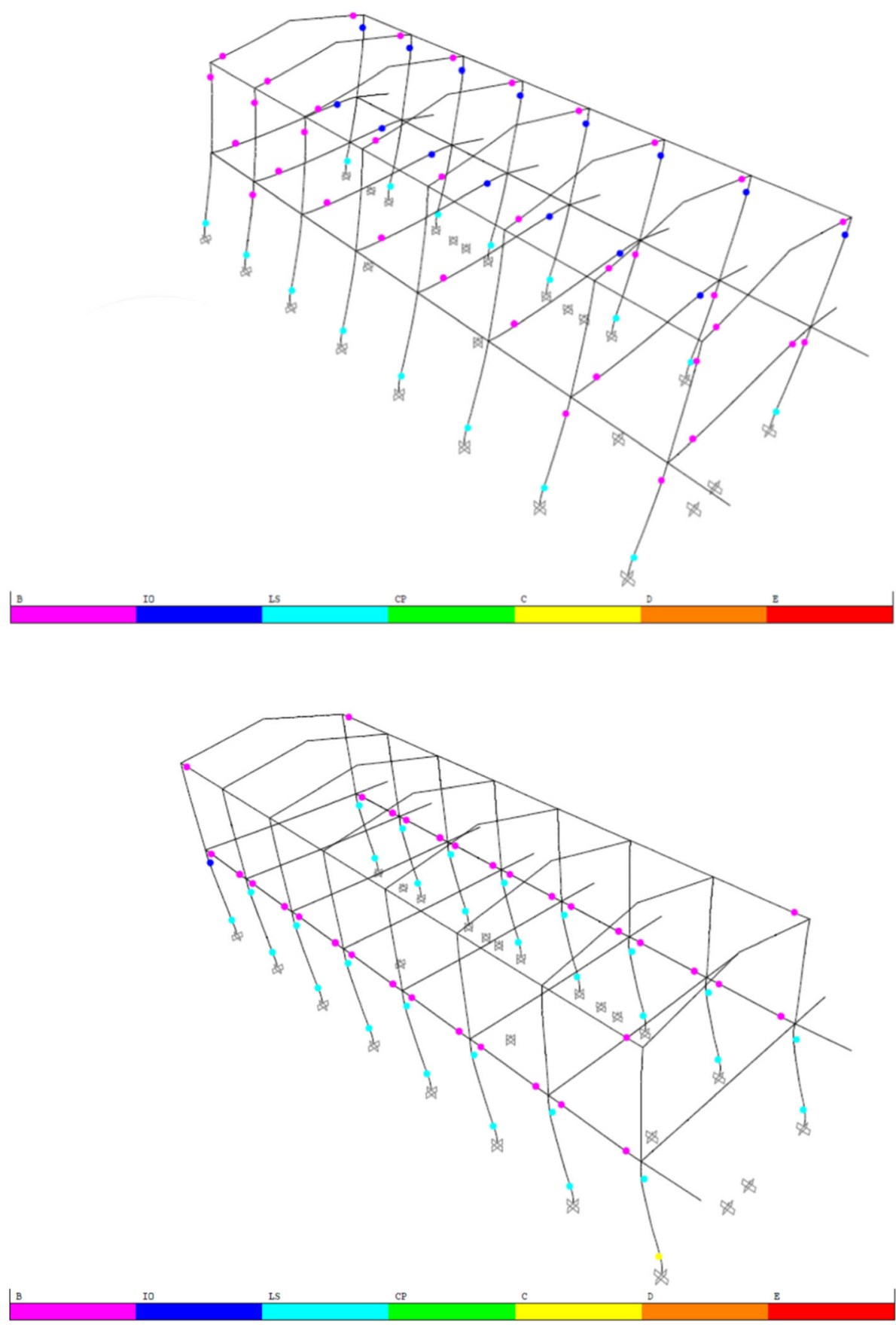

- The seismic demand expected with the seismic regulation of 1979 could be underestimated between 32 and $61 \%$ in school structures from 1 to 3 levels, located in the province of San Cristóbal, when compared with the seismic demand obtained with the current seismic code.

- Although according to their authors, the seismic hazard maps developed by the USGS cannot be considered complete for the eastern part of Hispaniola, they show that spectral accelerations for a $2 \%$ and a $10 \%$ probability in 50 years suggested by the current regulation could be underestimating the seismic demand for the entire area of the country located below the northern fault. This implies that more research is needed.

- It is necessary to develop or implement a code for the evaluation of existing structures in the Dominican Republic, since the current one was not intended for this purpose.

- The structural configuration of typical schools in the Dominican Republic promotes a poor seismic behavior (short column effect, buildings with irregular plan shapes, etc.) as observed during the Puerto Plata's earthquake in 2003. 

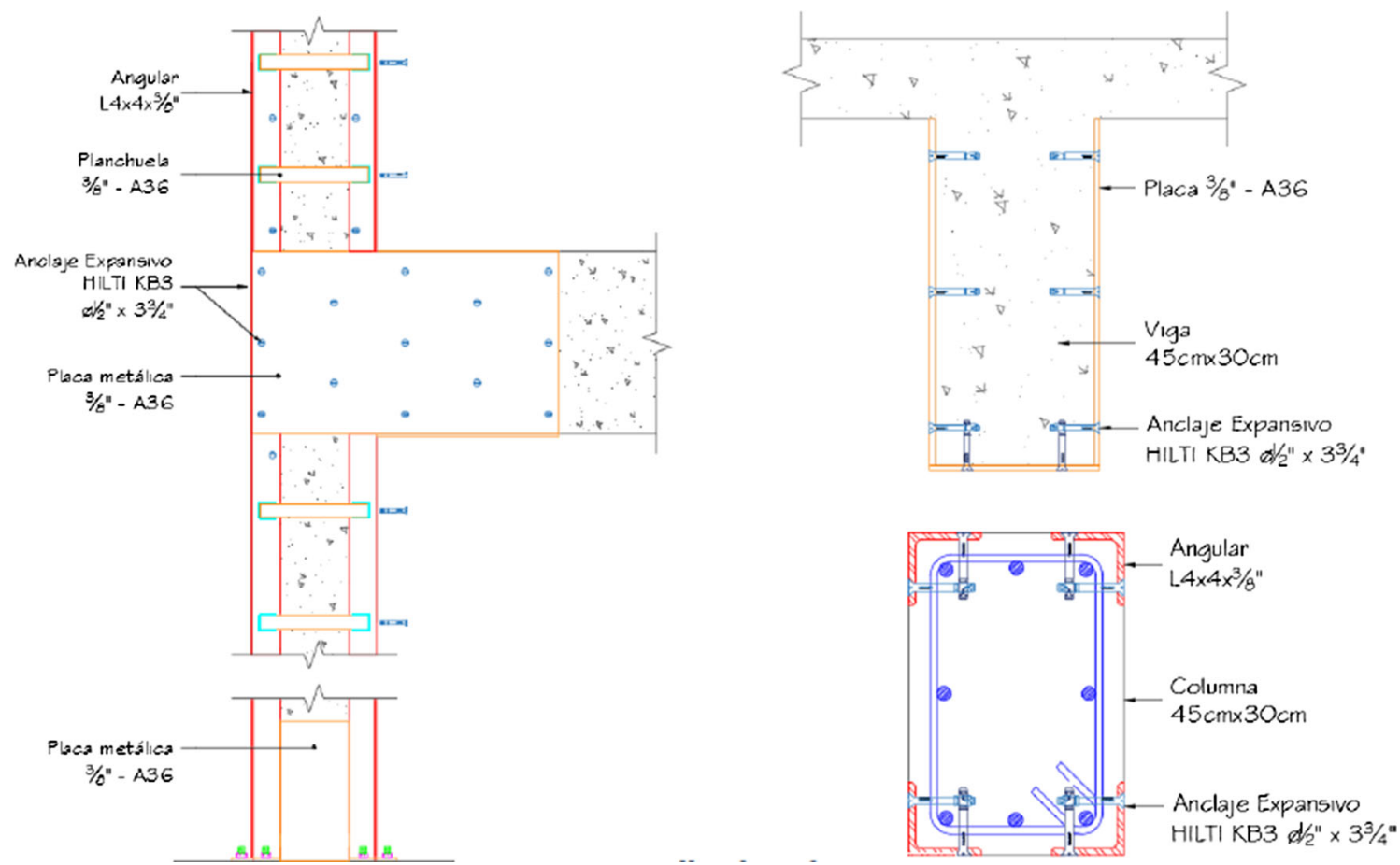

Fig. 23 Proposed reinforcement detail for beams and columns
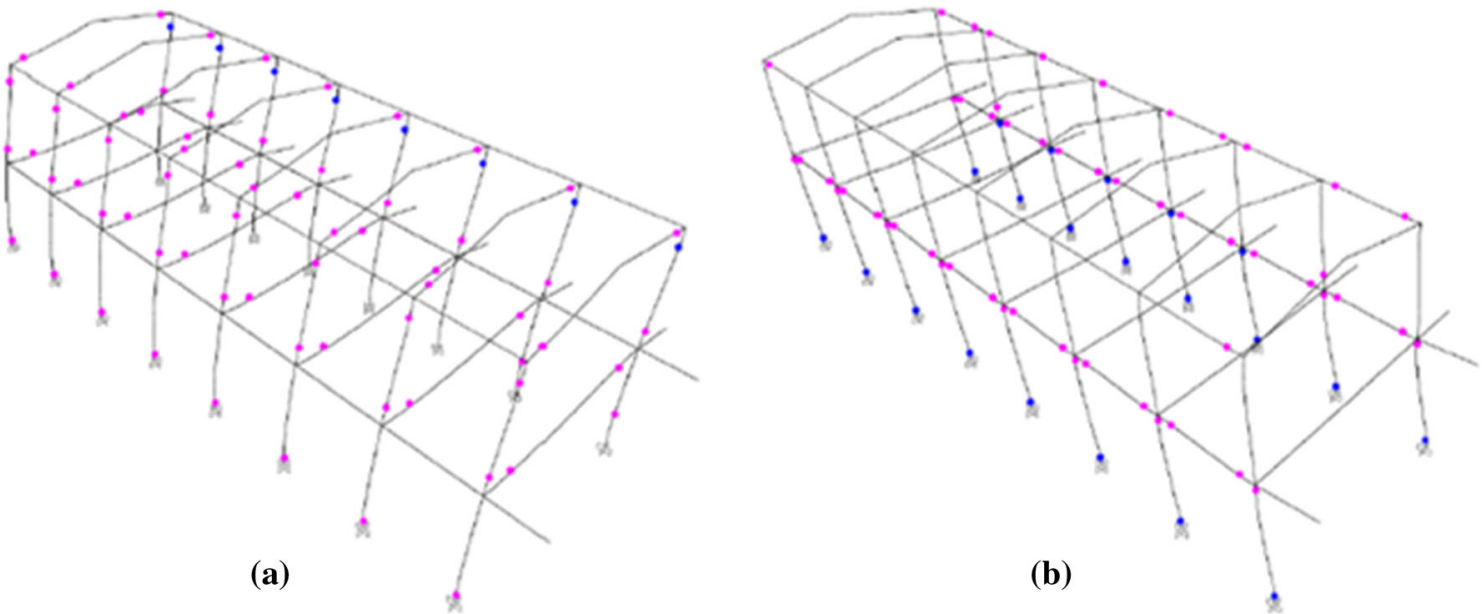

Fig. 24 Plastic hinge behavior for pushover analysis: $\mathbf{a} x$-direction and $\mathbf{b} y$-direction

- For the case of the Fernando Cabral Ortega School, concrete compressive strength obtained by destructive test resulted in a high coefficient of variation in both beam and column elements. This implies that more tests must be performed to obtain a representative resistance for the structural elements. However, it is important to mention that the other assessed schools had concrete strength well below those allowed by the design codes, which suggests that the quality control during the construction process was very deficient.
- The evaluation of the performance of the structure with the demand estimated according to the current seismic code showed that the expected level of damage exceeds the limit state for a structure with special occupation and, therefore, must be reinforced. The same observations apply for the remaining 21 schools evaluated in this project.

- When evaluating the proposed scheme reinforcement, the analysis results showed that the level of expected damage is within the limits for a special occupation 
structure, and therefore, it is demonstrated that this solution is adequate.

Acknowledgements The authors of this article express their gratitude to the Vice Rector for Research and Linking of INTEC, for having sponsored this project under the Grant VRIV/057/2015.

\section{Compliance with ethical standards}

Conflict of interest The authors of this article certify that they have no affiliations with or involvement in any organization or entity with any financial interest (such as honoraria; educational grants; participation in speakers' bureaus; membership, employment, consultancies, stock ownership, or other equity interest; and expert testimony or patentlicensing arrangements), or non-financial interest (such as personal or professional relationships, affiliations, knowledge or beliefs) in the subject matter or materials discussed in this manuscript.

Open Access This article is distributed under the terms of the Creative Commons Attribution 4.0 International License (http://creative commons.org/licenses/by/4.0/), which permits unrestricted use, distribution, and reproduction in any medium, provided you give appropriate credit to the original author(s) and the source, provide a link to the Creative Commons license, and indicate if changes were made.

\section{References}

AGIES (2001) AGIES NSE 6-10: Requisitos para obra existente: Disminución de riesgos, evaluación y rehabilitación. Normas de seguridad estructural de edificaciones y obras de infraestructura para la República de Guatemala, (NR-6:2001). Asociación Guatemalteca de Ingeniería Estructural y Sísmica

Almeida K (2011) Terremoto 22 de Septiembre 2003 en Puerto Plata. http://ppenlinea.blogspot.com/2011/09/terremoto-22-septiem bre-2003-en-puerto.html. Accessed 22 Sept 2011

Applied Technology Council, ATC-40 (1996) Seismic Evaluation and Retrofit of Concrete Building, vols 1 and 2, Report NO SSC 96-01. November 1996

Argudo J, Bravo F, y Yela R (1992) Metodología para la Reducción de la Vulnerabilidad Sísmica de Escuelas y Bibliotecas en Guayaquil. Noviembre 1992

ASCE7-05 (2005) Minimum design loads for buildings and other structures. American Society of Civil Engineers. ISBN 978-07844-1085-1

ASTM C 805/C805 M-13. Standard test method for rebound number of hardened concrete. ASTM International, West Conshohocken, PA. https://doi.org/10.1520/c0805_c0805m-13. www.astm.org

ASTM C42/C42 M-13. Standard test method for obtaining and testing drilled cores and sawed beams of concrete. ASTM International, West Conshohocken, PA. https://doi.org/10.1520/c0042_ c0042m-13. www.astm.org

Augenti N, Cosenza E, Dolce M, Manfredi G, Masi A, Samela L (2004) Performance of school buildings during the 2002 Molise, Italy earthquake. Earthq Spectra 20(S1):S257-S270

Benedetti D, Petrini Y (1984) V. Sulla vulnerabilitá sísmica di edifici in muratura: proposte di un método di valutazione. L'industria delle Costruzioni 149:66-78

Codia (2003) Evaluación Post-Sismo en la República Dominicana, El 22 de Septiembre del 2003, Lecciones Aprendidas. Capítulo de Riesgo. 16 de Octubre del 2003
COE (2009) Plan Nacional de Contingencia para Terremotos. Centro de Operaciones de Emergencia, Santo Domingo

Computers and Structures Inc. (2005) ETABS nonlinear version 9.0.4. Computers and Structures Inc., Berkeley

De León O (2005) Riesgo Sísmico en la República Dominicana. Academia de Ciencias de la República Dominicana, Santo Domingo

Delanoy RA (1995) Aspectos de Sismología Dominicana. Editorial Impresos Gabi, Santo Domingo

Di Sarno L, Manfredi G (2010) Seismic retrofitting with buckling restrained braces: application to an existing non-ductile RC framed building. Soil Dynamics and Earthquake Engineering 30(11):1279-1297

Di Sarno L, Manfredi G (2012) Experimental tests on full-scale RC unretrofitted frame and retrofitted with buckling restrained braces. Earthquake Eng Struct Dynam 41(2):315-333

EEFIT (2009) The L'Aquila, Italy earthquake of 6 April 2009: a preliminary field report by EEFIT. Earthquake Engineering Field Investigation Team, Institution of Structural Engineers, London

EERI (2009) The Mw 6.3 Abruzzo, Italy earthquake of April 6, 2009. Special earthquake report-June 2009

Federal Emergency Management Agency (FEMA-154) (2002a) Rapid visual screening of buildings for potential seismic hazards: a handbook, 2nd edn. Federal Emergency Management Agency, Washington

Federal Emergency Management Agency (FEMA-356) (2002b) Prestandard and commentary for the seismic rehabilitation of buildings. November 2000

FEMA 178 (1992) NEHRP handbook for the seismic evaluation of existing buildings. Building Seismic Safety Council, USA

FEMA 310 (1998) Handbook for the seismic evaluation of buildings-a prestandard. American Society of Civil Engineers, USA

FEMA 356 (2000) Prestandard and commentary for the seismic rehabilitation of buildings. American Society of Civil Engineers, USA

FEMA 356 (2002) Prestandard and commentary for the seismic rehabilitation of buildings. Federal Emergency Management Agency. November 2000

Formisano A (2012) Seismic damage assessment of school buildings after 2012 Emilia Romagna earthquake. Ingegneria Sismica, Anno XXIX, N. 2-3, aprile-giugno 2012

Formisano A, Castaldo C, Chiumiento G (2017) Optimal seismic upgrading of a reinforced concrete school building with metal-based devices using an efficient multi-criteria decision-making method. Structure and Infrastructure Engineering 13(11):1373-1389

Frankel A, Harmsen S, Mueller C, Calais E, Haase J (2011) Documentation for initial seismic hazard maps for haiti. Earthquake Spectra 27(S1):s23-s41. https://doi.org/10.3133/ ofr 20101067

Gómez SER (1987) Edificios Escolares y Desastres Naturales: Estudio de Caso sobre México y la Zona Centroamericana. UNESCO, División de Políticas y Planificación de la Educación, París

Lew HS, Simiu E, Gross JL. Starnes MA (2002) Manual for seismic and windstorm evaluation of existing concrete buildings for the Dominican Republic (NIST interagency/internal report (NISTIR), publication no. 6867). National Institute of Standards and Technology, Gaithersburg

López R, Martínez C (2003) Daños Observados en Puerto Plata, República Dominicana, Causados por el Terremoto del 22 de Septiembre del 2003. Revista Internacional de Desastres Naturales, Accidentes e Infraestructura Civil, vol 3(2)

Maracchini G, Clementi F, Quagliarini E, Lenci S, Monni F (2017) Preliminary study of the influence of different modelling choices and materials properties uncertainties on the seismic assessment of an existing RC school building. In: AIP conference 
proceedings volume 1863, 21 July, 2017, article number 450011. International Conference of Numerical Analysis and Applied Mathematics 2016, ICNAAM 2016; Rodos Palace Hotel Rhodes; Greece; 19 September through 25 September 2016

MOPC (2011) Reglamento para el Análisis y Diseño Sísmico de Estructuras R-001, Dirección General de Reglamentos y Sistemas (DGRS), Ministerio de Obras Públicas y Comunicaciones, Decreto No. 201-11

MOPC (2012) Reglamento para el Diseño y Construcción de Estructuras en Hormigón Armado R-033. Dirección General de Reglamentos y Sistemas (DGRS), Ministerio de Obras Públicas y Comunicaciones, Decreto No. 50-12

MOPC (2019) Requisitos para la evaluación estructural de edificios existentes o iniciados con fines de tramitar los planos para obtener la licencia de construcción, Dirección General de Reglamentos y Sistemas (DGRS), Ministerio de Obras Públicas y Comunicaciones. Enero 2019

O’ Reilly H (2002) Desarrollo de los códigos de construcción en República Dominicana, Seminario Internacional de Desastres Naturales y Manejo de Emergencias, 6 y 7 de Diciembre 2002, Santiago Republica Dominicana

O' Reilly H et al (2004) Estudio de Amenaza Sísmica de la Republica Dominicana. Proyecto (ECHO/TPS/219/2003/2006), Agosto 2004

O’ Reilly GJ, Perrone D, Fox M, Monteiro R, Filiatrault A, Lanese I, Pavese A (2019) System identification and seismic assessment modeling implications for Italian school buildings. J Perform Constr Facil 33(1):04018089

OEA/ODSMA (1992) Programa de Reducción de la Vulnerabilidad del Sector Educativo a los Peligros Naturales (PRVSEPN), Resolución CP/RES.593(922/92)

ONESVIE (2014) Reducción de la vulnerabilidad sísmica de las edificaciones escolares en la Provincia de San Cristóbal. Informe final del proyecto, Julio 2014

Rodgers JE (2012) Why schools are vulnerable to earthquakes. 15 world conference of earthquake engineering (WCEE), Lisboa 2012

SEOPC (1979) Recomendaciones Provisionales para el Análisis Sísmico de Estructuras M-001. Departamento de Normas, Reglamentos y Sistemas (DNRS), Secretaria de Estado de Obras Públicas y Comunicaciones (MOPC), Diciembre 1979

Wong DD, Samudio R, y Mora H (1997) Determinación de la Vulnerabilidad y Estimación de Day Estimación de Daños ante los Desastres Naturales en los Centros Educativos en la República de Panamá. Universidad Tecnológica de Panamá, Centro de Proyectos. Panamá. 1997

Publisher's Note Springer Nature remains neutral with regard to jurisdictional claims in published maps and institutional affiliations. 